De Jure: Jurnal Hukum dan Syar'iah

Vol. 13, No. 1, 2021, h. 14-31

ISSN (Print): 2085-1618, ISSN (Online): 2528-1658

DOI: http://dx.doi.org/10.18860/j-fsh.v13i1.12122

Available online at http://ejournal.uin-malang.ac.id/index.php/syariah

\title{
The Interpretation of Misconduct Act as A Reason to Dismiss President: An Ethical Approach
}

\author{
Putu Eva Ditayani Antari \\ Universitas Pendidikan Nasional \\ evaditayaniantari@undiknas.ac.id
}

\begin{abstract}
:
The President of Indonesia gets the supervision of the Senate as regulated by the constitution. The Senate has the authority to dismiss the president at the recommendation of the House of Representatives if the president is deemed to have committed treason against the state, corruption or bribery, serious crimes, and misconduct acts or is deemed no longer eligible for president. Misconduct act is a reason for dismissing a president does not have legal certainty because the constitution does not limit the intent of the misconduct act itself. At the same time, the Constitutional Court Act in Indonesia has extended the meaning of this misconduct act. This paper will discuss the meaning of the misconduct act from an ethical perspective and comparative study. Furthermore, it also describes the appropriateness of the limits on misconduct as regulated in the Constitutional Court Act with the intention of constitution drafting for amendment. These legal problems will then be studied using normative methods through historical, comparative, and interpretation approaches then presented on a descriptively-analysis paper. The results of the study indicate that a misconduct act is an act that degrades the dignity of the position as president. Misconduct acts have a broader meaning than criminal acts but can also violate unwritten norms that are determined as law in society.
\end{abstract}

Keywords: dismissal of president; interpretation; misconduct act.

\section{Abstrak:}

Presiden Indonesia mendapat pengawasan dari Senat sebagaimana diatur dalam konstitusi. Senat memiliki kewenangan untuk memberhentikan presiden atas rekomendasi DPR jika presiden dianggap telah melakukan pengkhianatan terhadap negara, korupsi atau penyuapan, kejahatan berat, dan tindakan tidak senonoh atau dianggap tidak lagi memenuhi syarat untuk menjadi presiden. Perbuatan tercela menjadi alasan memberhentikan seorang presiden yang tidak memiliki kepastian hukum, karena konstitusi tidak membatasi maksud dari perbuatan tercelaitu sendiri. Padahal UU MK di Indonesia telah memperluas makna dari 
maksud perbuatan maksiat ini. Makalah ini akan membahas tentang pengertian perbuatan salah dari sudut pandang etika. Lebih lanjut, juga menggambarkan kesesuaian batasan perbuatan tercela sebagaimana diatur dalam UU MK dengan maksud penyusunan konstitusi untuk diubah. Permasalahan hukum tersebut kemudian akan dikaji dengan menggunakan metode normatif melalui pendekatan historis, komparatif, dan interpretasi, kemudian disajikan dalam makalah analisis deskriptif. Hasil penelitian menunjukkan bahwa perbuatan tercela merupakan perbuatan yang merendahkan martabat jabatan sebagai presiden. Perbuatan tercela memiliki makna yang lebih luas dari tindak pidana, namun bisa juga pelanggaran atas norma-norma tak tertulis yang berlaku sebagai hukum di masyarakat.

Kata Kunci: Interpretasi, pemberhentian presiden; perbuatan tercela.

\section{Introduction}

A democratic state is a form of state developed to prevent arbitrary actions by the aristocracy or political leaders of the state acting as the state government. Democracy allows the participation of the people as part of the government and supervises the running of the government. In addition, the legitimacy of government power is also obtained from the people through the general election process. In this way, it is the government's responsibility to hold the people accountable for implementing its governmental duties. Indonesia, as one of the largest democracies in the world, adopted the trias politica proposed by Montesquieu to share state power, but not only divided into 3 (three) branches of state power as expressed by Efi Yulistyowati, et al. He stated that state power in Indonesia does indeed apply the teachings of trias politica, namely the legislative, executive and judiciary. However, there are also branches of examination and consultative powers, as regulated in the 1945 Constitution (from now on abbreviated to the 1945 Constitution) before amendments. Meanwhile, the amendment post of consultative power has been removed from the structure of state institutions. It leaves 4 (four) other branches of power, namely the legislative, executive, judicial, and executive branches.

Each of these branches of state power is then carried out by state institutions, such as the Congress, the House of Representatives, the Senate, the President, the Constitutional Court, the Supreme Court, the Judicial Commission, and the Supreme Audit Agency. Each of these state institutions is parallel to carry out supervision and balance against other state institutions called checks and balances. Ibn Sina Chandanegara stated checks and balances as of the core of constitutionalism, creating a balance of power between the different parts of the government to check and supervise one another. Then how is the supervision of the President in the presidential system?

The presidential system of government or what is often referred to as the congressional system, in which the executive power is elected through elections and separated from the legislative power so that the legislative and executive institutions have the same legitimacy of office because they are the result of direct elections by the people. So that the two institutions are equal. The presidential system has the characteristics of centralizing the power of the state government to the president and 
a solid presidential position because of the guarantee of the term of office in the constitution (fixed-term executive). According to C.F Strong, a presidential government system is a fixed executive who has the following characteristics: ${ }^{1} 1$ ) The President as the head of state and head of government; 2) The President has the authority to appoint ministers and other officials; 3 ) The President directly elected by the people and has a permanent term of office; 4 ) The president and parliament have an equal position; and 5) The President is responsible to the constitution.

Based on the 1945 Constitution, the President is a political official whom the people directly elect through political contestation, which is called a general election. The President holds the position of head of government as well as head of state. Article 4 paragraph (1) of the 1945 Constitution states that the provisions in the constitution itself limit the power of the President to administer the government. Jimly Asshiddiqie interpreted that there were state government powers that were according to the constitution and there were also state government powers that were not according to the law. What is meant by the constitution can also be distinguished between those that are explicitly determined in the constitution and some that are not explicitly stipulated in the constitution. ${ }^{2}$ This is also an argument for why the president's power in Indonesia shows the features of executive heavy.

Based on the separation of powers and the principle of checks and balances, the president is still under supervision to balance his considerable powers in the Indonesian government system. The Indonesian House of Representatives carries out supervision of the president with the existence of supervisory rights over the government, namely the right to interpellation, the right to inquiry, and the right to express an opinion. The results of the supervision are then submitted to the MPR to be followed by process of dismissal during the term of office. This mechanism is a mechanism of government accountability to the people as a source of legitimacy for state power, as regulated in Article 1 paragraph (2) of the 1945 Constitution. Abdul Mukthie Fadjar stated that dismissal of the President and/or Vice President in the middle of a term of office is a consequence of the state implementing the government system presidential. Where the mechanism for dismissing the president and / or vice president during his term of office must be regulated in the constitution of the country concerned, in order to guarantee the stability of the government. ${ }^{3}$ a) The dismissal of the president in Indonesia is carried out through a political mechanism called impeachment by the People's Consultative Assembly. Abdul Rasyid Thalib concluded the reasons for dismissing the President and / or Vice President based on the formulation of Article 7A of the 1945 Constitution, namely if the President and / or the Vice President are proven; b) committing a violation of the law, in the form of treason against the state, corruption, bribery, other serious crimes, or other despicable acts, which are a criminal aspect; c) no longer meet the requirements as

\footnotetext{
${ }^{1}$ Putu Eva Ditayani Antari, "Penerapan Model Impeachment Dalam Pemberhentian Presiden Dan/Atau Wakil Presiden Di Indonesia," Jurnal Hukum Undiknas 3, no. 1 (2016): 17-45.

2 Jimly Asshiddiqie, Pengantar Hukum Tata Negara Indonesia (Jakarta: PT. Raja Grafindo Persada, 2009).

${ }^{3}$ Abdul Mukti Fajar, Hukum Konstitusi Dan Mahkamah Konstitusi (Jakarta: Konstitusi Press dan Citra Media Yogyakarta, 2006).
} 
President and / or Vice President as aspects of state administration and administration. ${ }^{4}$

Based on these provisions, it can be seen that there is no explanation regarding the meaning of despicable acts. Abdul Rasyid Thalib then categorized the despicable act into criminal aspects for a reason for dismissing the President and/or Vice President. Meanwhile, Article 10 paragraph (3) letter a of Law Number 24 of 2003 concerning the Constitutional Court (abbreviated as the Law on the Constitutional Court) provides a limitation on the definition of a disgraceful act, namely actions that can degrading the dignity of the President and / or the Vice President. Furthermore, in the study the explanation of the article does not further explain what is meant by an act that can be degrading as president. The limitation on the definition of this despicable act is insufficient to provide a sense of legal certainty in the mechanism for dismissing the president in Indonesia.

Disgraceful actions that can degrade one's dignity are very diverse in terms of decency, morality, religion, and morals that apply in society. In addition, criminal acts that can be used as reasons for the dismissal of the President and/or Vice President as regulated in Article 7A of the 1945 Constitution are also despicable acts that can humiliate the President and/or Vice President, namely treason, corruption, bribery, and criminal acts other weight. So that the definition of this despicable act needs to be emphasized again, and the criteria or limits are determined so as not to cause confusion and problems in the future. Without a clear interpretation of this matter, it is possible that the process of dismissing the President in Indonesia to be politicized based on differences in views between the President and the House of Representatives.

Until this research was carried out, no President and/or Vice President had been dismissed from office. However, the extent of the meaning of this disgraceful act can be illustrated through the case of the dismissal of the Regent of Garut, Aceng Fikri. He was dismissed for being involved in a brief marriage scandal with children. This has become a polemic in society because it is considered to have violated ethical values, namely to marry children illegally and then divorce them only through short messages text. ${ }^{5}$ Comparative study also show that disgraceful reasons have also been used to propose the dismissal of Bill Clinton. The reason for his dismissal was due to an alleged affair with an intern officer in White House named Monica Lewinsky. This scandal is proven by Lewinsky's confession and evidence of telephone conversations between the two. Therefore, based on the United States Constitution, Clinton can be dismissed on the grounds of disgrace. ${ }^{6}$ Referring to these two examples, the interpretation of the meaning of a disgraceful act is identical to a sexual scandal committed by a state official. However, the meaning of a disgraceful act is very broadly related to the norms in society. This needs to be limited to support the

\footnotetext{
${ }^{4}$ Abdul Rasyid Thalib, Wewenang Mahkamah Konstitusi Dan Implikasinya Dalam Sistem Ketatanegaraan Republik Indonesia (Bandung: Citra Aditya Bakti, 2006).

5 Tempo.co, “Aceng, Bupati Pertama Dimakzulkan Karena Pernikahan,” Tempo.Co, last modified 2012, accessed July 4, 2021, https://nasional.tempo.co/read/449969/aceng-bupati-pertama-dimakzulkan-karenapernikahan.

6 Tempo, "Tiga Presiden Amerika Ini Pernah Terkena Proses Pemakzulan,” Tempo.Co, last modified 2019, accessed July 4, 2021, https://dunia.tempo.co/read/1280657/tiga-presiden-amerika-ini-pernahterkena-proses-pemakzulan.
} 
idea of legal certainty and efforts to politicize the dismissal of the president and/or vice president.

Based on this description, it can be stated that the problem formulations to be examined in this paper are: 1) The meaning of disgraceful act as a reason for dismissing the president; and 2) Adherence to the limits of disgraceful acts according to the Constitutional Court Law with the intention of drafting the amendments to the 1945 Constitution. This type of research used in this research is normative research. According to Soerjono Soekanto and Sri Mamudji, normative research is research that examines secondary data or library materials. This research is also called dogmatic research or library research. ${ }^{7}$ This research is classified as a normative study because this study discusses the interpretation of the misconduct act that regulates the constitution and the consistency between the definition of the misconduct act by the Constitutional Court Act and the amendment drafter meanings. This research focuses on the norm on constitution and act, without considering the implementation in the community.

The legal materials used in this study include primary legal material, secondary legal material, and tertiary legal material. Primary legal material used in this research is the Indonesian Constitution 1945, Indonesian Constitutional Court Act, and Constitutional Court Regulation Number 21 of 2009 concerning Procedures in Deciding the Opinion of the House of Representatives regarding Alleged Violations by the President and/or Vice President. The secondary legal material uses books and journals or thesis related to the presidential system, constitutional court, interpretation methods, and other relevant topic. Then, the tertiary legal material used is a dictionary and an article on a website or newspaper to discuss the research topic.vThis study uses legal materials collection techniques through literature study from statutory regulations, books, journals, and dictionaries. The legal materials analysis used is qualitative. This is because this research analyzes data based on concepts, theories, principles, laws and regulations, doctrines, or the views of the researchers themselves. ${ }^{8}$ Therefore, this paper is a descriptive analysis related to interpreting the norm for legal certainty through the procedure to dismiss the President in Indonesia.

\section{The Evecutive Heavy on Presidential System}

A simple government system can be defined as a work procedure for state administration to achieve mutually agreed goals. A deeper understanding of the government system can refer to the opinion of legal experts on the definition of a government system, as stated by Ismail Sunny. He argues that the government system is a particular system that explains how the relationship between the highest state equipment in a country. The government system can be divided into a parliamentary system of government and a presidential system of government. According to Mahfud M.D., another government system outside the two government systems. is a mixed system (quasi) of the two government systems, or there is also a referendum. ${ }^{9}$

\footnotetext{
${ }^{7}$ Ishaq, Metode Penelitian Hukum Dan Penulisan Skripsi, Tesis, Serta Disertasi (Bandung: Alfabeta, 2017).

${ }^{8}$ I Made Pasek Diantha, Konsepsi Teoritis Penelitian Hukum Normatif (Denpasar: Udayana Press, 2016).

${ }^{9}$ Moh. Mahfud M.D., Perdebatan Hukum Tata Negara Pasca Amandemen Konstitusi (Jakarta: Rajawali Press, 2011).
} 
The presidential government system is built on the theory of separation of powers or the Trias Politica proposed by Montesquieu. This is a form of hatred and resistance to the king's absolute power, who has excellent power and carries out the functions of power that exist in a country collectively. As a result of the absolute king's power, the government was run according to the ruler's wishes and tended to act arbitrarily towards its citizens. Therefore, a presidential government system was developed which aims to prevent absolute government in a country. ${ }^{10}$ With the separation of powers in a country, state power will not be concentrated in one hand but separated into each branch of state power that has an equal position. No one branch of power exceeds other branches of power.

In the presidential system of government, the head of state and head of government are united so that the head of state simultaneously functions as the head of government. Furthermore, the character of the presidential government system can also be seen from the pattern of relations between the executive and legislative institutions, where there is a clear-cut separation of power. With this strict separation, in the presidential government system the formation of government does not depend on the political process in the legislative body. ${ }^{11}$ The separation of the legislative and executive institutions is also accompanied by equal positions of the legislative and executive institutions. The legislative institution cannot dissolve the executive branch and vice versa. This is related to the checks and balances mechanism that is also implemented in the presidential government system so that the two institutions can monitor each other's performance.

The legitimacy of the executive, who is the head of state and head of government, comes from the people because the people directly elect it in a general election. The direct election of the president and vice president implies that the president is directly responsible to the people and is not easily overthrown by the legislature, which is seen as more guaranteeing the stability of the government. In other words, Laica Marzuki stated that the position of the president in the presidential government system does not absolutely require political support from the parliament or people's representative institutions, because the president gets legitimacy through direct elections by the people. The term of office of the president has also been clearly stipulated in the constitution, so that it cannot be replaced even though it has received minimal support from the parliament or people's representative institutions. ${ }^{12}$

The president in the presidential government system serves as the head of state, and the head of government is often referred to as the single chief executive. According to Deny Indrayana, this single chief executive position causes the span of executive power in the presidential government system not only to touch the realm of executive power, but also to the legislative function and authority in the judiciary. ${ }^{13}$ This is shown by the variety of powers of the President outside the executive sector

\footnotetext{
${ }^{10}$ Moh. Kusnardi and Harmaily Ibrahim, Pengantar Hukum Tata Negara Indonesia (Jakarta: Pusat Studi Hukum Tata Negara UI, 2005).

${ }^{11}$ Saldi Isra, Pergeseran Fungsi Legislasi Menguatnya Model Legislasi Parlementer Dalam Sistem Presidensial Indonesia (Jakarta: PT. Raja Grafindo Persada, 2010).

${ }^{12}$ Laica Marzuki, Berjalan-Jalan Di Ranah Hukum : Pikiran-Pikiran Lepas Prof. Dr. H. M. Laica Marzuki, S.H. (Jakarta: Sekretariat Jenderal dan Kepaniteraan Mahkamah Konstitusi RI, 2006).

${ }^{13}$ Deny Indrayana, Amandemen UUD 1945 Antara Mitos Dan Pembongkaran (Bandung: Penerbit Mizan, 2007).
} 
as mentioned in the 1945 Constitution, including the authority to submit a bill, approve the ratification of laws, formulate statutory regulations, appoint ambassadors and consuls, hold the highest power over the military, and granting clemency, amnesty and abolition.

Executive heavy in the presidential system, with the concentration of power in the president, does not mean that the president's power is unlimited and absolute, but still provides an accountability mechanism to the president. The form of accountability if the president makes mistakes as regulated in the constitution, namely the termination of the term of office, which is called the fixed term executive exclusion clause. This dismissal mechanism shows an effort to fulfill the principle of equality before the law that the president is not an individual immune to law because of his position. Before going through the judicial process, the president who is proven to have violated the law will receive political sanctions in the form of dismissal from his position as a form of accountability to constituents. Then, the position of president and/or vice president still requires obedience to the rule of law, just like other citizens.

\section{The Dismisal of President as A Liability Rule}

The authority to dismiss the president and/or vice president in the presidential system is the people's authority as constituents. This is because the legitimacy of power in the president's office and/or vice president comes from the people who elect them directly. The people also have the right to take back this power by dismissing the president and/or vice president during their term of office. The authority to dismiss the next president and/or vice president on behalf of the people is held by people's representative institutions because the democratic system is a representative democracy. In Indonesia, based on the 1945 Constitution, the authority to dismiss the president and/or vice president lies with Congress as the people's representative.

During his term of office in Indonesia, the dismissal of the president is often identified with the term impeachment or impeachment. The term impeachment itself can be found in a book written by Hamdan Zoelva. He stated that the term impeachment was chosen because it is standard Indonesian, and the word "makzul" itself means accordingly, namely to stop holding office or abdicate. Meanwhile, the term impeachment is a foreign term which, according to him, has a narrower meaning, which is only one part of the impeachment process as a stage of indictment. ${ }^{14}$

\section{Types of President Dismission Process}

Dismissal of a president during his term of office can be carried out in 2 (two) ways, namely through a juridical mechanism carried out by a judicial institution or a political mechanism implemented by a people's representative institution. The 1945 Constitution itself regulates the existence of a legal and political mechanism that is carried out in dismissing the president. The legal mechanism is shown by the authority possessed by the Constitutional Court as the institution with authority to judge reasons for dismissing the president. Meanwhile, the political mechanism is held by the MPR as the holder of people's sovereignty, which will hold a special session regarding the decision to dismiss the president.

\footnotetext{
${ }^{14}$ Hamdan Zoelva, Pemakzulan Presiden Di Indonesia (Jakarta: Sinar Grafika, 2011).
} 
Saleh and Muklish stated that in a country that adopts a presidential system of government, there are two models of dismissal of the president during his term of office, namely the impeachment model and the forum previlegiatum (special court) model. Both models of dismissal of the President and / or Vice President are classified based on the mechanism that must be followed in their dismissal. Impeachment is the dismissal of the President and / or Vice President in the middle of their term of office by the legislative body. On the other hand, in the forum previlegiatum (special court) the dismissal of the President and / or Vice President during his term of office is carried out by a judicial institution specially formed to adjudicate regarding the dismissal of the President and / or Vice President during that term of office. ${ }^{15}$ Fisrt, Impeachment, is a mechanism for dismissing the President during his term of office which is carried out by political institutions that are representatives of all the people and through political assessments and decisions with strict conditions and mechanisms, for example impeachment conducted by Congress against the President of the United States. ${ }^{16}$ So in impeachment, the president is removed from office through a political mechanism and by representative political institutions.

Impeachment in the view of Michael J. Gerhard based on his research in the United States, is a unique legislative decision that can only be carried out in accordance with a constitutionally constrained framework. Impeachment itself shows two very important aspects, namely the legality or constitutional aspect and the aspect of political accountability on the other. ${ }^{17}$ From the legality aspect, efforts are made to prevent impeachment from any practices that can reduce the trust of the parties in an honest impeachment process, so that any differences between the president and the legislature cannot be used as an excuse to carry out the impeachment. The existence of these different views should be addressed as part of the checks and balances of the constitution. ${ }^{18}$ Thus, the majority power in the legislature cannot remove the president from office without being accompanied by legal and constitutional reasons and legal procedures adopted in the constitution. ${ }^{19}$

From a political perspective, decision-making regarding impeachment in the legislature can show inconsistent decision-making in the judiciary because decisionmaking in the legislature is often influenced by a balance of the composition of political interests. Therefore, many legal experts have the view that the presidential impeachment process is nothing but a political process. In the presidential impeachment process there are also various influences that often occur, such as political battles between political parties in the legislative body, pressure groups or interest groups, and the mass media which have a special role. ${ }^{20}$ Thus, impeachment of the president will be difficult if the composition of political power in the representative institutions is balanced between the supporting parties and the

\footnotetext{
${ }^{15}$ M. Saleh and Muklish, Impeachment Presiden Dan/Atau Wakil Presiden (Sebuah Tinjauan Konstitusional) (Surabaya: Bina Ilmu Offset, 2010).

${ }^{16}$ M.D., Perdebatan Hukum Tata Negara Pasca Amandemen Konstitusi.

${ }^{17}$ Michael J. Gerhard, The Federal Impeachmet Process (A Constitutional and Historival Analysis)

(Chicago: The University of Chivago Press, 2005).

18 Ibid.

${ }^{19}$ Zoelva, Pemakzulan Presiden Di Indonesia.

${ }^{20}$ Ibid.
} 
opposition parties to the president. Impeachment will only be successful if it supports the majority of political forces in representative institutions.

Richard M. Pious added, impeachment is also often constrained by the strength of the position of the president directly elected by the people, where the decisions of the people's representatives in representative institutions will greatly depend on the votes of voters and constituents of political parties. This was exemplified in the impeachment process of President Bill Clinton, where the Congress's decision to reject impeachment was highly influenced by the mass media and various poll results published in the media, and did not rely too much on constitutional provisions even though it was clearly proven that there had been violations of the law by the President Bill Clinton at the time. ${ }^{21}$ Therefore, in impeachment, political support is more influential in making decisions about whether a president is dismissed or not from his position. The constellation of parliamentary political support for the president will influence the outcome of the decision more than factual evidence that shows that there have been violations committed by the president, which in the constitution are regulated as reasons for dismissing the president from its position.

Second, Forum Previlegiatum, the model for dismissing the president in his second term of office is through a particular legal proceeding or forum previlegiatum. In this model, the president's dismissal during his term of office is carried out through the mechanism of a special court and not through a political legislature. This particular court is the first and last instance whose verdict is final. The judicial mechanism in this special court is accelerated without going through the conventional level of examination from the lower level as is done in the courts in general. ${ }^{22}$ According to Mahfud M.D., forum previligiatum is the overthrow of the president through a special constitutional court which is basically a serious violation of law stipulated in the constitution by a legal decision as well. He also stated that the Constitutional Court's authority to examine, try and decide the opinion of the DPR that the President and / or the Vice President have committed violations of the law in the form of treason against the state, corruption, bribery, other serious crimes or despicable acts; and / or no longer eligible as President and / or Vice President, is the practice of the forum previligiatum in Indonesia. ${ }^{23}$ So in his view, the Constitutional Court is a special court to adjudicate and decide on allegations of legal violations that have been committed by the President and/or the Vice President. If the Court proves the alleged violation of the law, the DPR can follow up on the MK decision to the MPR. Then the MPR can exercise its authority to dismiss the President and/or Vice President from their positions through a special session attended by at least $3 / 4$ of the MPR members and obtaining the approval of at least $2 / 3$ of the number of MPR members present.

In the history of the Indonesian constitution itself, this forum previligiatum has been implemented as adopted in the 1949 Constitution of the Republic of Indonesia (KRIS) and the 1950 Provisional Basic Law (UUDS). President and other state officials during his term of office. However, there is a rule that regulates the existence

\footnotetext{
${ }^{21}$ Keith E. Wittinggton, Constitutional Construction, Divided Powers and Constitutional Meaning (USA: Harvard University Press, 2001).

${ }^{22}$ Saleh and Muklish, Impeachment Presiden Dan/Atau Wakil Presiden (Sebuah Tinjauan Konstitusional).

${ }^{23}$ M.D., Perdebatan Hukum Tata Negara Pasca Amandemen Konstitusi.
} 
of a special court for the president, vice president, and other state officials if they are suspected of having committed crimes and violations of office and crimes and other violations committed during their term of office. This can be seen in the provisions of Article 148 KRIS and Article 106 paragraph (1) of the 1950 UUDS, which authorize the Supreme Court as a special court to try allegations that the president, vice president, and other state officials have committed crimes and violations of office as well as crimes and violations. Others were determined by law during his term of office. The judicial process can be carried out while the official concerned is still in office or after resigning from his position. ${ }^{24}$

Nandang Alamsyah Deliar Noor stated no mechanism for dismissing the president, vice president, and other state officials in the previlegiatum forum as regulated in the 1949 KRIS and the 1950 UUDS. Criminal cases are also committed by certain persons, such as the president, vice president, and other state officials, but do not regulate the dismissal mechanism from their posts. The dismissal of the president, vice president, and other state officials if proven to have committed a criminal act will still be carried out through the prevailing political or bureaucratic mechanisms. ${ }^{25}$ Apart from that, the dismissal of the President, vice president, and other state officials based on the 1949 KRIS and the 1950 UUDS cannot be carried out by the Supreme Court also because no further provisions are governing whether the Supreme Court has the authority to dismiss the President or other state officials from their positions if proven guilty. However, it is only given the authority to adjudicate criminal offenses, and the sanctions are only criminal penalties.

There are 2 (two) countries that can be used as a model for implementing the previlegiatum forum as an institution for dismissing the President during his term of office, namely France and South Korea. The French constitution provides that the President and government officials can be prosecuted for removal through a particular court forum. The reasons stated in the French constitution for being able to dismiss the President, and government officials are if the president and government officials are proven to have committed treason against the state, committed criminal crimes, and other improper acts. Special courts to remove the president and government officials are the jurisdiction of the Supreme Court.

Meanwhile, in South Korea, the president's dismissal from his term of office based on the constitution is the authority of the Constitutional Court, not the parliament. In this dismissal mechanism, the participation of the parliament is as the party proposing the motion to dismiss the president, so that the dismissal of the president can only be carried out through a decision of the Constitutional Court which is preceded by an indictment in the form of a motion filed by parliament regarding the dismissal of the president. In addition to the president, dismissal during this term of office can also be carried out for main state organizations such as the prime minister, members of the state council, heads of executive ministries, judges, judges of the Constitutional Court, members of the General Election Commission, heads and members of the Audit and Inspection Board as well as other public officials assigned by law. ${ }^{26}$

\footnotetext{
${ }^{24}$ Zoelva, Pemakzulan Presiden Di Indonesia.

${ }^{25}$ Nandang Alamsyah Deliarnoor, "Forum Previligiatum Dalam Negara Hukum Berdasarkan UndangUndang Dasar 1945" (Universitas Padjajaran, Bandung, 2006).

${ }^{26}$ Saleh and Muklish, Impeachment Presiden Dan/Atau Wakil Presiden (Sebuah Tinjauan Konstitusional).
} 
The existence of a dismissal mechanism for the president and other prominent state organizations during their term of office as stipulated in the South Korean Constitution aims to protect the constitution by holding the president and other prominent state organizations accountable for their legal obligations or their actions, including requesting accountability for allegations or allegations committing certain criminal acts. Dismissal of the president and other main state organizations during their term of office also aims to discipline the implementation of their duties and obligations, because in South Korea the dismissal by its nature is not a criminal complaint but a disciplinary complaint. ${ }^{27}$

\section{The Reasons for President Dismiss in Indonesia}

Hamdan Zoelva, after collecting various reasons for the dismissal of presidents in various countries, reached a conclusion that the reasons for dismissing the President were at least in the following 4 (four) groups: ${ }^{28} 1$ ) political reasons because the President's accountability is rejected; 2) reasons for violating constitutional law, such as violations of the constitution and laws and regulations; 3 ) reasons proven to have committed a criminal act; and 4) a combination of these reasons. Meanwhile, based on Article 7A of the 1945 Constitution, it is known that a President can be dismissed from his position by Congress if the President is proven to have violated the law in the form of treason against the state, corruption, bribery, other serious crimes, or disgraceful acts or if proven no longer eligible as President and/or the Vice President so that the reasons for the dismissal of the President and/or Vice President can be classified as reasons of violating the law and reasons for not meeting the requirements of President and/or Vice President. The reasons for violating the law can then be further classified into unlawful acts, including serious crimes and misconduct acts. ${ }^{29}$

State treason based on Constitutional Court Regulation Number 21 of 2009 is defined as a criminal offense against state security as regulated in law. Hamdan Zoelva, based on his research, explains that treason against the state is a criminal act that can threaten state security as regulated in Title I Book II of the Criminal Code (KUHP) and other criminal laws, such as crimes of terrorism, crimes regarding efforts to spread the teachings of communism. / Marxism-Leninism, as well as crimes aimed at eliminating or changing Pancasila as the basis of the state. Besides in the explanation of Act Number 23 of 2003 concerning the General Election of the President and Vice President, does not betray the state, is described as having never been involved in a separatist movement, never taking unconstitutional or violent actions to change the basis of the state, and never violating the 1945 Constitution.

Furthermore, corruption as an example of white-collar crime is also a valid reason used to propose the president's dismissal during his term of office. The definition of corruption in the Black Law Dictionary is an act that aims to obtain unofficial benefits for oneself or other people or groups by abusing their position. The abuse of official power as a characteristic of corruption was also pointed out by Huntington, who stated that corruption was the behavior of public officials who

\footnotetext{
${ }^{27}$ Ryan Muthiara Wastia, "Mekanisme Impeachment Di Negara Dengan Sistem Presidensial: Studi Perbandingan Mekanisme Impeachment Di Indonesia Dan Korea Selatan," Mimbar Hukum - Fakultas Hukum Universitas Gadjah Mada 31, no. 2 (2019): 237.

${ }^{28}$ Zoelva, Pemakzulan Presiden Di Indonesia.

${ }^{29}$ Ibid.
} 
deviated from the norms adopted by society for personal gain. Meanwhile, Constitutional Court Regulation Number 21 of 2009 is defined as a criminal act of corruption regulated in law. This corruption crime has been strictly regulated in Law No. 31 of 1999 concerning Eradication of Corruption Crimes as amended in Act Number 20 of 2001 concerning Amendments to Act Number 31 of 1999 concerning the Eradication of Corruption (Corruption Act), which defines corruption as an act of enriching oneself or another person or a corporation that can harm state finances or the country's economy.

Closely related to corruption is bribery, which was also mentioned as the reason for proposing the president's dismissal to the Senate. Bribery as regulated in Constitutional Court Regulation Number 21 of 2009, definition also refers to the provisions of the law. The definition of the criminal act of bribery can be seen in Article 13 of the Anti-Corruption Act, which formulates the act of giving gifts or promises to civil servants by considering the power or authority attached to the position or position.

Apart from the three reasons mentioned above, the president's dismissal in Indonesia can also be proposed if the president is proven to have committed serious crimes other than those previously mentioned. In Article 1 number 10 Constitutional Court Regulation Number 21 of 2009, other serious crimes are defined as a criminal offense that carries a punishment in the form of imprisonment of 5 (five) years or more. So the qualification of a severe criminal offense that can be used as a reason for dismissing the President and/or Vice President is limited by the length of the imprisonment period for which the act is threatened.

This explicit limitation is not found when looking for the meaning of a despicable act in Constitutional Court Regulation Number 21 of 2009. Misconduct acts in these regulations are only interpreted as acts that can degrade the President and/or vice President's dignity. This explanation is still broad so that it can lead to multiple and multiple interpretations. The reasons that have been put forward as the basis for the dismissal of the President in Indonesia can also be classified as despicable. Apart from that, this disgraceful act can also be an act that violates the norms, which are outside the legal norms that are upheld by society. Therefore, disgraceful acts constitute a very flexible reason for dismissing the President and/or Vice President, which, if misused or politicized, will injure legal certainty in the process of dismissing the President and/or Vice President.

In addition, the president of Indonesia can also be dismissed if he no longer meets the requirements as President and/or Vice President. In Constitutional Court Regulation Number 21 of 2009, it is explained that the requirements for being President and/or Vice President are the conditions stipulated in Article 6 of the 1945 Constitution and laws which further regulate the requirements of the President and/or Vice President, such as law laws governing the general election of the President and Vice President.

\section{Interpretation of Misconduct Act on Etichal Approach as a Violation of The Law}

The definition of misconduct acts in the Constitutional Court Act and PMK No. 21 of 2009 has a broad, general, abstract, and vague meaning, giving rise to multiple interpretations. This is because it is unclear whether the misconduct act only includes other crimes besides the aforementioned criminal offenses and serious crimes or whether the misconduct act includes other acts other than the criminal act. 
Thus, it is necessary to understand the meaning of the phrase misconduct as an excuse to dismiss the President and/or Vice President to provide clarity and limits on said misconduct act. Etymologically, the definition of a misconduct act can be seen by understanding the meaning of the 2 (two) constituent words, namely action, and disgrace. Actions in the Great Indonesian Dictionary (KBBI) are defined as done (done) or an action or behavior or behavior. An action can be interpreted positively or negatively. Positive action is an action that benefits not only himself but also benefits others.

Conversely, if action is interpreted negatively, most society is often seen as an action that can harm itself and others. Furthermore, the word misconduct comes from the word "cela" which in KBBI is defined as something that causes imperfections or defects, or deficiencies. The word misconduct can also be interpreted as a disgrace or insult, criticism, or criticism. Misconduct itself is then interpreted as something that should be reprehensible, inappropriate, and should not be repeated. Thus, the phrase etymologically misconduct act can be understood as an act or behavior that is inappropriate or disgraceful, resulting in disability in a person so that the action should not be repeated.

Sociologically, the criteria for a misconduct act can be measured by the suitability of the act to the norms prevailing in society. The behavior of a person in society needs to be regulated to regulate one's behavior in society and create order in society. To regulate such behavior, norms emerge, namely, religious norms, norms of decency, norms of decency, and legal norms. So, a despicable act must be seen from its conformity with the norms prevailing in that society.

Misconduct acts can also include violations of criminal law and other violations of law, as well as violations of religious values, morals, decency and morality. Hamdan Zoelva also added that misconduct acts can also be in the form of violations of the President and / or Vice President of the constitutional obligations of his position as long as the violations in such a way can undermine his dignity as President and / or Vice President. ${ }^{30}$

Hamdan Zoelva further stated that seen from the spirit of the formulation of the 1945 Constitution which explicitly includes forms of serious crimes as reasons for dismissing the President and / or Vice President, this shows that the reasons for dismissing the President and / or Vice President are limited to acts of violating the law equal with a serious crime only. Such unlawful acts can undermine the dignity of the President and / or the Vice President which results in public distrust of the President and / or Vice President concerned so that it will lose the legitimacy of the people. ${ }^{31}$

The reasons misconduct in the dismissal of the President and / or Vice President by Lusia Indrastuti adopted the term misdemeanors contained in the Constitution of the United States. Article II Section (4) of the United States Constitution states that one of the reasons for dismissing the President, Vice President, and civil servants is misdemeanors. This word is then contained in Article

\footnotetext{
${ }^{30}$ Hamdan Zoelva, Impeachment Presiden : Alasan Tindak Pidana Pemberhentian Presiden Menurut UUD 1945 (Jakarta: Konstitusi Press, 2005).

31 Ibid.
} 
7A of the 1945 Constitution as a disgraceful act which becomes one of the reasons for the dismissal of the President and / or Vice President. ${ }^{32}$

This opinion seems to need to be explored further by looking at the viewpoint of the formers of the United States Constitution. They understand misdemeanors, including mal and corrupt administration, and neglect of duty, and misconduct in office (neglect of obligations). In practice the dismissal of the President and / or Vice President in the United States shows that the phrase high crimes and misdemeanors refers to crimes that directly endanger the state, including treason, bribery, espionage, obstructing the judicial process at court. federal (obstuction of justice in federal proceedings), sabotage of state property (sabotages on government property), and embezzling or stealing (stealing) state money. ${ }^{33}$ So these misdemeanors refer more to criminal acts that can harm the state and neglect their obligations to their position.

The definition of misdemeanors can also be seen in the Black Law Dictionary, which states that a misdemeanor is a more severe offense than an infraction, yet not legally called a felony. It is generally punishable by a fine or imprisonment of one year or less (misdemeanors are more serious crimes than violations but are not legally classified as serious crimes. Usually punishable by a fine or imprisonment of one year or less). Based on this formula, misdemeanors can be classified as crimes or criminal acts but are not serious crimes. The punishment for misdemeanors is usually in the form of a fine or in the form of imprisonment of one year or less than one year.

Meanwhile, in essence as a public official, as stated by Sastra Djatmika, quoted by Philipus M. Hadjon, the President who is elected through the general election process is a state official. ${ }^{34}$ The president gets legitimacy through direct elections by the people and those who are elected will hold office within the period specified in the constitution (fixed term). The power of the President does not come from the support of the majority of members of the legislature as in the parliamentary system of government without a clear term of office.

The position of the president as head of state and head of government in Indonesia shows that the president's powers are inherently vast. The position of a president with great power must also be accompanied by the ethics of the position itself as a guideline for how a president should behave, what is inappropriate and appropriate to implement. Ethics is often synonymous with morals, but the two terms are different things. This was stated by Paul Ricoeur, who linked the two terms to two different traditions of philosophical thought. The moral is associated with the thought tradition of Immanuel Kant (deontological point of view), which refers to obligations, norms, principles of action, imperatives. On the other hand, the term ethics is associated with Aristotle's tradition of teleological thought. It is understood as the goal of life shared and for others in a just institution. So ethics is understood more as a reflection of good/bad, right/wrong, what to do, or how to do good or right, while moral is an obligation to do good or what should be done. Even though

\footnotetext{
${ }^{32}$ Lusia Indrastuti, "Presiden Dan Atau Wakil Presiden Menurut Undang-Undang Dasar 1945," Eksplorasi XXIV, no. 1 (2012): 12-21.

${ }^{33}$ Zoelva, Impeachment Presiden : Alasan Tindak Pidana Pemberhentian Presiden Menurut UUD 1945.

${ }^{34}$ Philipus M. Hadjon, Pengantar Hukum Administrasi Indonesia (yOGYAKARTA: Gajah Mada University Press, 2008).
} 
the two terms are different, they are both related where ethics is a philosophical reflection on morals. ${ }^{35}$

The relationship between the term ethics and morals can also be seen from the viewpoint $\mathrm{K}$. Bertens obtained from his understanding of the term ethics in the Big Indonesian Dictionary. The term ethics is interpreted by K. Bertens into the following 3 formulas: ${ }^{36}$ 1) ethics in the sense of moral values and norms that are used by a person or group in regulating their behavior; 2) ethics in the sense of a collection of moral principles or values; and 3) ethics in the sense of the knowledge of what is good and what is bad. Based on the understanding of the nature of the office of the president and the ethics of the position, it can be said that actions that are contrary to the ethics of the office of the president are deeds that are classified as despicable. A president in his position as head of state and head of government, and a public official should avoid this despicable act that is not following the ethics of his position. This is because office ethics is related to the president's morality, which reflects his dignity, integrity, credibility, dignity as a president, both in the eyes of his people and leaders of other countries. So it becomes crucial for a president to maintain his behavior in order to avoid all despicable actions that are not following the ethics of his position because, of course, this will show the imperfect morality of the president and result in the loss of people's trust which is a source of legitimacy for the president's office.

The importance of maintaining the behavior of the president as head of state and head of government constitutionally in the 1945 Constitution is manifested by the existence of political sanctions in the form of dismissal in his term of office if it is proven that he has committed acts that are not following the ethics of office. It is hoped that the president and/or vice president can become a guide or example for the community by having high dignity and consistently maintaining their behavior. Of course, with such a moral burden, a president and/or vice president should avoid all deviant behavior, both criminal acts and violations of law and social norms.

An example of an act that is not classified as a criminal act but constitutes an act that can undermine his / her dignity as president and/or vice president, namely if a Muslim president and/or vice president does not respond fast in the month of Ramadan, instead he holds a meal with family and relatives. - his relatives when other Muslims fast. This is not an act that can be categorized as a criminal act. However, of course, it has violated religious norms that he adheres to and causes gossip in the community, which later can undermine the dignity of the president and/or vice president. It also shows that a president and/or vice president cannot maintain his behavior and authority as a head of state and head of government who should be a role model and role model for the people but shows the opposite.

Based on the description, it can be seen that the ethics of the position as president and vice president are related to the prevailing norms in society, so that a disgraceful act is an act that is contrary to these norms. So disgraceful acts are a form of violation of religious norms, norms of decency, norms of decency, and legal norms that can lead to sanctions in society to undermine the dignity of a president and/or vice president. The legal norms referred to here are not only in criminal law but all

\footnotetext{
${ }^{35}$ Haryatmoko, Etika Publik Untuk Integritas Pejabat Publik Dan Politisi (Jakarta: Gramedia Pustaka Utama, 2011).

${ }^{36}$ K. Bertens, Etika Edisi Revisi (Yogyakarta: Kanisius, 2013).
} 
forms of positive law contained in every statutory regulation. Therefore, the disgraceful act in the provisions of Article 7A of the 1945 Constitution can be defined as: 1) violations of the constitution related to constitutional conventions, such as the president acting arbitrarily to close down a political party by a presidential decree, in which the dissolution of political parties in the 1945 Constitution is the authority of the Constitutional Court. Another example is the president dissolving the House of Representative, which violates the provisions of Article 7C of the 1945 Constitution; 2) violation of the norms of decency and decency that apply in society in the context of social, national and state life. For example the president has a special relationship with a woman other than his wife and this is shown openly in public. Or when the president and/or vice president have committed an act of polygamy which is a violation of the ethics of public official. It is classified as a violation of the law when it is associated with the marriage act and the state official law; 3 ) violation of religious norms adhered to in accordance with the path of office, for example a president who is a Muslim never performs the obligation to pray even does not attend his religious holidays in congregation with other state officials. It become a discourse in public and get a reprimand by the Indonesian Ulema Council; 4) Criminal acts other than those described in the provisions of Article 7A UUDNRI 1945 (treason against the state, corruption, bribery and other serious crimes), such as the president committing light maltreatment in the form of slapping one of his subordinates and this being processed by the police and receiving media publication mass; or 5) Other violations of law that are not included in the violation of criminal law or related to the requirements as president and/or vice president. For example, violations in the field of civil law.

\section{Conclusion}

Based on the description of the discussion above, the following conclusions can be conveyed: An act of contempt as an act that undermines the dignity of the President can be interpreted as an act that is classified as a criminal act or other act that is contrary to the norms prevailing in society, namely religious norms, norms of decency, and norms of morality. This is a consequence of the President as a public official who is obliged to maintain his behavior in society to remain respected. The meaning of disgraceful acts formulated in the Constitutional Court Act and Constitutional Court Regulation Number 21 of 2009 is still broad and multiple interpretations. Therefore, it is not following the wishes of the drafters of the amendments to the 1945 Constitution so that the reasons for dismissing the President are clear and cannot be politicized by certain groups. This is only to ensure the stability of the President's office in the presidential government system. Meanwhile, the suggestion that can be submitted based on the above conclusions is to amend the Constitutional Court Act and Constitutional Court Regulation Number 21 of 2009, which contains clear boundaries about the meaning of despicable acts, such as violations of religious norms, decency, and moral norms that make people lose respect for their leaders. Even if deemed necessary, this can also be emphasized in the explanatory part of the two regulations as a reference for Constitutional Court judges to make decisions.

\section{Bibilography:}

Antari, Putu Eva Ditayani. "Implementasi Fugsi Pengawasan Dewan Perwakilan Rakyat Dalam Upaya Memperkuat Sistem Presidensial Di Indonesia." Refleksi 
Hukum 4, no. 2 (2020): 247.

- "Penerapan Model Impeachment Dalam Pemberhentian Presiden Dan/Atau Wakil Presiden Di Indonesia." Jurnal Hukum Undiknas 3, no. 1 (2016): 17-45.

Asshiddiqie, Jimly. Pengantar Hukum Tata Negara Indonesia. Jakarta: PT. Raja Grafindo Persada, 2009.

Bertens, K. Etika Edisi Revisi. Yogyakarta: Kanisius, 2013.

Deliarnoor, Nandang Alamsyah. "Forum Previligiatum Dalam Negara Hukum Berdasarkan Undang-Undang Dasar 1945." Universitas Padjajaran, Bandung, 2006.

Diantha, I Made Pasek. Konsepsi Teoritis Penelitian Hukum Normatif. Denpasar: Udayana Press, 2016.

Fajar, Abdul Mukti. Hukum Konstitusi Dan Mahkamah Konstitusi. Jakarta: Konstitusi Press dan Citra Media Yogyakarta, 2006.

Gerhard, Michael J. The Federal Impeachmet Process (A Constitutional and Historival Analysis). Chicago: The University of Chivago Press, 2005.

Hadjon, Philipus M. Pengantar Hukum Administrasi Indonesia. yOGYAKARTA: Gajah Mada University Press, 2008.

Haryatmoko. Etika Publik Untuk Integritas Pejabat Publik Dan Politisi. Jakarta: Gramedia Pustaka Utama, 2011.

Indrastuti, Lusia. "Presiden Dan Atau Wakil Presiden Menurut Undang-Undang Dasar 1945." Eksplorasi XXIV, no. 1 (2012): 12-21.

Indrayana, Deny. Amandemen UUD 1945 Antara Mitos Dan Pembongkaran. Bandung: Penerbit Mizan, 2007.

Ishaq. Metode Penelitian Hukum Dan Penulisan Skripsi, Tesis, Serta Disertasi. Bandung: Alfabeta, 2017.

Isra, Saldi. Pergeseran Fungsi Legislasi Menguatnya Model Legislasi Parlementer Dalam Sistem Presidensial Indonesia. Jakarta: PT. Raja Grafindo Persada, 2010.

Kusnardi, Moh., and Harmaily Ibrahim. Pengantar Hukum Tata Negara Indonesia. Jakarta: Pusat Studi Hukum Tata Negara UI, 2005.

M.D., Moh. Mahfud. Perdebatan Hukum Tata Negara Pasca Amandemen Konstitusi. Jakarta: Rajawali Press, 2011.

Marzuki, Laica. Berjalan-Jalan Di Ranah Hukum : Pikiran-Pikiran Lepas Prof. Dr. H. M. Laica Marzuki, S.H. Jakarta: Sekretariat Jenderal dan Kepaniteraan Mahkamah Konstitusi RI, 2006.

Saleh, M., and Muklish. Impeachment Presiden Dan/Atau Wakil Presiden (Sebuah Tinjauan Konstitusional). Surabaya: Bina Ilmu Offset, 2010.

Tempo.co. "Aceng, Bupati Pertama Dimakzulkan Karena Pernikahan." Tempo.Co. Last modified 2012. Accessed July 4, 2021. https://nasional.tempo.co/read/449969/aceng-bupati-pertama-dimakzulkankarena-pernikahan.

Tempo. "Tiga Presiden Amerika Ini Pernah Terkena Proses Pemakzulan." Tempo.Co. Last modified 2019. Accessed July 4, 2021. https://dunia.tempo.co/read/1280657/tiga-presiden-amerika-ini-pernahterkena-proses-pemakzulan.

Thalib, Abdul Rasyid. Wewenang Mahkamah Konstitusi Dan Implikasinya Dalam Sistem Ketatanegaraan Republik Indonesia. Bandung: Citra Aditya Bakti, 2006. 
31 | De Jure: Jurnal Hukum dan Syar'iah, Vol. 13 No. 1 Tahun 2021

Wastia, Ryan Muthiara. "Mekanisme Impeachment Di Negara Dengan Sistem Presidensial: Studi Perbandingan Mekanisme Impeachment Di Indonesia Dan Korea Selatan." Mimbar Hukum - Fakultas Hukum Universitas Gadjah Mada 31, no. 2 (2019): 237.

Wittinggton, Keith E. Constitutional Construction, Divided Powers and Constitutional Meaning. USA: Harvard University Press, 2001.

Zoelva, Hamdan. Impeachment Presiden: Alasan Tindak Pidana Pemberhentian Presiden Menurut UUD 1945. Jakarta: Konstitusi Press, 2005.

_. Pemakzulan Presiden Di Indonesia. Jakarta: Sinar Grafika, 2011. 